\title{
Trialkylborane-Assisted $\mathrm{CO}_{2}$ Reduction by Late Transition Metal Hydrides
}

\author{
Alexander J. M. Miller, Jay A. Labinger, and John E. Bercaw \\ Arnold and Mabel Beckman Laboratories of Chemical Synthesis, California Institute of \\ Technology, Pasadena, California 91125
}

\begin{abstract}
Trialkylborane additives promote reduction of $\mathrm{CO}_{2}$ to formate by bis(diphosphine) $\mathrm{Ni}$ (II) and $\mathrm{Rh}$ (III) hydride complexes. The late transition metal hydrides, which can be formed from dihydrogen, transfer hydride to $\mathrm{CO}_{2}$ to give a formate-borane adduct. The borane must be of appropriate Lewis acidity: weaker acids do not show significant hydride transfer enhancement, while stronger acids abstract hydride without $\mathrm{CO}_{2}$ reduction. The mechanism likely involves a pre-equilibrium hydride transfer followed by formation of a stabilizing formate-borane adduct.
\end{abstract}

\section{Introduction}

Efficient catalytic conversion of $\mathrm{CO}_{2}$ to fuels and chemicals could be a major contributor towards achieving carbon neutrality. ${ }^{1} \mathrm{We}$ have recently reported (stoichiometric) reactions relevant to conversion of syngas to organic products, making use of a combination of a metal carbonyl complex, a nucleophilic late transition metal hydride, and an intramolecularly appended Lewis acid. ${ }^{2}$ Because some syngas conversion catalysts are known to convert $\mathrm{CO}_{2}$ as well - for example, the common $\mathrm{CuO} / \mathrm{ZnO} / \mathrm{Al}_{2} \mathrm{O}_{3}$ catalyst can effectively convert a mixture of $\mathrm{H}_{2}, \mathrm{CO}_{2}$, and $\mathrm{CO}$ to methanol ${ }^{3}-$ we thought it might be worthwhile to examine the chemistry of our $\mathrm{CO}$-reducing systems with $\mathrm{CO}_{2}$.

The two main approaches to $\mathrm{CO}_{2}$ reduction currently under consideration are electrocatalytic reduction, ${ }^{1 \mathrm{a}}$ in which protons and electrons are added sequentially (and/or concertedly), and direct hydrogenation. ${ }^{1 b, c}$ Most of the electrocatalytic systems operate at quite reducing potentials to generate $\mathrm{CO}$ and $\mathrm{H}_{2} \mathrm{O}$, while hydrogenation (under forcing pressures) more commonly produces formic acid (Scheme 1). Lewis (particularly those based on alkali and alkaline earth metals) and Brønsted acids have shown promise in improving electrocatalytic $\mathrm{CO}_{2}$ reduction, notably with low-valent Fe porphyrins. ${ }^{4}$ Bimetallic catalysts, including the active site of the enzyme [NiFe] $\mathrm{CO}$ dehydrogenase, appear to function by having one metal bound to $\mathrm{C}$ while the other acts as a Lewis acid to bind $\mathrm{O} .{ }^{5}$ Lewis acids such as $\mathrm{A}_{10} \mathrm{O}_{\mathrm{X}}$, and $\mathrm{TiO}_{\mathrm{x}}$ appear to play an important role in heterogeneous catalysts that convert $\mathrm{CO}_{2}$ (and $\mathrm{CO}$ ) to $\mathrm{CH}_{4}$.

Several examples involving boron compounds have also been reported. The conversion of a diboronyl $\mathrm{B}-\mathrm{B}^{7}$ or secondary borane $\mathrm{B}-\mathrm{H}^{8}$ bond to a $\mathrm{B}-\mathrm{O}$ bond helps drive $\mathrm{CO}_{2}$ reduction by homogeneous $\mathrm{Cu}$ - and Ni-based catalysts, respectively. Activation of dihydrogen by "frustrated Lewis pairs" can also lead to reduction of $\mathrm{CO}_{2}$; products include methanol (after hydrolysis). ${ }^{9}$ All of these reactions are stoichiometric in boron; catalysis is precluded by the

jal@caltech.edu; bercaw@caltech.edu.

Supporting Information Available. Accompanying NMR spectra for reactions described in the Experimental Section. This material is available free of charge via the Internet at http://pubs.acs.org. 
difficulty of cleaving the strong $\mathrm{B}-\mathrm{O}$ bonds, unless strong $\mathrm{Si}-\mathrm{O}$ bonds are formed using silane additives. ${ }^{10}$

We report here that the late transition metal hydrides, as well as the partially-reduced metal carbonyl components of our $\mathrm{CO}$ reductive coupling system, are able to reduce $\mathrm{CO}_{2}$ to formate, with the Lewis acidic trialkylboranes playing a key role. Although no catalysis has yet been achieved, the formate-borane adducts obtained appear to be considerably less strongly bound than in the above-discussed systems, suggesting that this may be a promising new approach to $\mathrm{CO}_{2}$ reduction.

\section{Results and Discussion}

The Re carbonyl cation $\left[\left(\mathrm{Ph}_{2} \mathrm{P}\left(\mathrm{CH}_{2}\right)_{2} \mathrm{~B}\left(\mathrm{C}_{8} \mathrm{H}_{14}\right)\right)_{2} \mathrm{Re}(\mathrm{CO})_{4}\right]\left[\mathrm{BF}_{4}\right]\left([\mathbf{1}]\left[\mathrm{BF}_{4}\right]\right)$, bearing pendent alkylboranes in the secondary coordination sphere of the metal, reacts with $\left[\mathrm{HPt}(\mathrm{dmpe})_{2}\right]\left[\mathrm{PF}_{6}\right](\mathrm{dmpe}=1,2$-bis(dimethylphosphino)ethane), but not with the analogous Ni hydride, to give boroxycarbene 2 (Scheme 2). ${ }^{2 \mathrm{a}}$ (Complex $\mathbf{2}$ can also be prepared by reduction of 1 with $\mathrm{NaHBEt}_{3}$.) Similarly, DuBois has found that $\mathrm{CO}_{2}$ is reduced to $\left[\mathrm{HCO}_{2}\right]^{-}$ by $\left[\mathrm{HPt}(\mathrm{dmpe})_{2}\right]\left[\mathrm{PF}_{6}\right]$, whereas $\left[\mathrm{Bu}_{4} \mathrm{~N}\right]\left[\mathrm{HCO}_{2}\right]$ transfers hydride to $\left[\mathrm{Ni}(\mathrm{dmpe})_{2}\right]^{2+}$ to yield $\left[\mathrm{HNi}(\mathrm{dmpe})_{2}\right]^{+}$(Scheme 3). ${ }^{11}$ The hydride donor strengths $\left(\Delta G_{\mathrm{H}^{-}}\right.$; smaller values correspond to stronger hydride donors) of $\left[\mathrm{HPt}(\mathrm{dmpe})_{2}\right]^{+},\left[\mathrm{HNi}(\mathrm{dmpe})_{2}\right]^{+}$and $\left[\mathrm{HCO}_{2}\right]^{-}$ have been determined to be $42.5,50.9$ and $44.2 \mathrm{kcal} \cdot \mathrm{mol}^{-1}$ respectively ${ }^{12}$ (the last value is estimated from the observation that $\left[\mathrm{HCO}_{2}\right]^{-}$has $\Delta G_{\mathrm{H}^{-}}$similar to that of $\left[\mathrm{HPt}(\mathrm{depe})_{2}\right]^{+}$ (depe $=1,2$-bis(diethylphosphino)ethane), ${ }^{11}$ the $\Delta G_{\mathrm{H}^{-}}$of which was recalculated from the originally published value ${ }^{12 \mathrm{a}}$ using DuBois' more recent $\mathrm{p} K_{a}$ value $^{12 \mathrm{c}}$ ).

Boroxycarbene 2 can serve as a hydride source, releasing $\mathrm{H}_{2}$ upon treatment with water or weak acids, ${ }^{2 \mathrm{~d}}$ but the above results show that it is intermediate in hydride strength between $\left[\mathrm{HNi}(\mathrm{dmpe})_{2}\right]\left[\mathrm{PF}_{6}\right]$ and $\left[\mathrm{HPt}(\mathrm{dmpe})_{2}\right]\left[\mathrm{PF}_{6}\right]$; is it strong enough to reduce $\mathrm{CO}_{2}$ ? Admission of $1 \mathrm{~atm} \mathrm{CO}_{2}$ to a thoroughly degassed solution of 2 (formed in situ from [1] $\left[\mathrm{BF}_{4}\right]$ and $\mathrm{NaHBEt}_{3}$ in $\mathrm{C}_{6} \mathrm{D}_{5} \mathrm{Cl}$ ) led after a few minutes to a new ${ }^{1} \mathrm{H}$ NMR resonance at $\delta 8.44 .{ }^{31} \mathrm{P}$ NMR showed complete consumption of $\mathbf{2}$ and formation of a new species with a single signal whose chemical shift was similar to that for [1] $]^{+}$; IR spectroscopy indicated a [trans$\left.\mathrm{L}_{2} \operatorname{Re}(\mathrm{CO})_{4}\right]^{+}$substructure (a single strong stretch at $1993 \mathrm{~cm}^{-1}$ ) as well as a reduced $\mathrm{C}=\mathrm{O}$ functionality $\left(1620 \mathrm{~cm}^{-1}\right)$. These data are consistent with hydride transfer from 2 to $\mathrm{CO}_{2}$ giving $1 \cdot\left(\mathrm{HCO}_{2}\right)$ (Scheme 4$)$; the same species could be obtained by addition of $\left[\mathrm{Bu}_{4} \mathrm{~N}\right]$ $\left[\mathrm{HCO}_{2}\right]$ to $[1]\left[\mathrm{BF}_{4}\right]$ in $\mathrm{C}_{6} \mathrm{D}_{5} \mathrm{Cl}$. The apparent symmetry exhibited by the NMR spectra suggests the operation of a fluxional process that exchanges formate between boranes, likely via reversible oligomerization (Scheme 4). After about an hour, large amounts of precipitate formed along with disappearance of the NMR signals assigned to $\mathbf{1} \cdot\left(\mathrm{HCO}_{2}\right)$; probably this is due to formation of an oligomeric species $\left[\mathbf{1} \cdot\left(\mathrm{HCO}_{2}\right)\right]_{\mathrm{n}}$, with $-\mathrm{B}-\mathrm{OC}(\mathrm{H}) \mathrm{O}-\mathrm{B}-$ linkages. Similar behavior has been observed for some of the $\mathrm{CO}$ reduction products studied previously. ${ }^{2 \mathrm{~d}}$

The observation that $\mathbf{2}$ reacts with $\mathrm{CO}_{2}$ to yield $\left[\mathbf{1} \cdot\left(\mathrm{HCO}_{2}\right)\right]$ does not necessarily indicate that $\mathbf{2}$ is a stronger hydride donor than $\left[\mathrm{HCC}_{2}\right]^{-}$, since the $\mathrm{B}-\mathrm{O}$ interaction in $\mathbf{1} \cdot\left(\mathrm{HCO}_{2}\right)$ (and the two $\mathrm{B}-\mathrm{O}$ interactions in $\left.\left[\mathbf{1} \cdot\left(\mathrm{HCO}_{2}\right)\right]_{\mathrm{n}}\right)$ presumably afford(s) additional stabilization. Similarly, although transfer of hydride from $\left[\mathrm{HNi}(\mathrm{dmpe})_{2}\right]^{+}$to $\mathrm{CO}_{2}$ should be uphill by $\sim 7$ $\mathrm{kcal} \cdot \mathrm{mol}^{-1}$, addition of $\mathrm{CO}_{2}$ to a mixture of $\left[\mathrm{HNi}(\mathrm{dmpe})_{2}\right]\left[\mathrm{PF}_{6}\right]$ and $[1]\left[\mathrm{BF}_{4}\right]$ produced significant amounts of $\mathbf{1} \cdot\left(\mathrm{HCO}_{2}\right)$ over 24 hours at room temperature. This reaction did not proceed to completion, as evidenced by the presence of unreacted $\left[\mathrm{HNi}(\mathrm{dmpe})_{2}\right]^{+}$; the chemical shifts for the (single) remaining Re-containing species were intermediate between those for $[\mathbf{1}]^{+}$and $\mathbf{1} \cdot\left(\mathrm{HCO}_{2}\right)$, suggesting an equilibrium between these species. (No boroxycarbene 2 was observed.) The precipitate which again formed over time could be 
partially dissolved by addition of pyridine; the resulting solution showed a slightly shifted ${ }^{1} \mathrm{H}$ NMR signal for the formate group $(\delta 8.88)$ and $t w o{ }^{31} \mathrm{P}$ NMR signals $(\delta 1.95 \mathrm{~d}$, $\left.2.98 \mathrm{~d}, J_{\mathrm{PP}}=77 \mathrm{~Hz}\right)$, consistent with formation of the asymmetric pyridine adduct $\mathbf{1} \cdot\left(\mathrm{HCO}_{2}\right)$ $\left(\mathrm{C}_{5} \mathrm{H}_{5} \mathrm{~N}\right)$ (Scheme 5).

Similar chemistry is promoted by a simple trialkylborane, which could imply that Re may simply be a spectator in the reaction involving $[\mathbf{1}]^{+}$: when $\left[\mathrm{HNi}(\mathrm{dmpe})_{2}\right]\left[\mathrm{PF}_{6}\right]$ was allowed to react with $\mathrm{CO}_{2}(1 \mathrm{~atm})$ in the presence of ${ }^{t} \mathrm{Bu}\left(\mathrm{CH}_{2}\right)_{2} \mathrm{~B}\left(\mathrm{C}_{8} \mathrm{H}_{14}\right)$ in $\mathrm{C}_{6} \mathrm{D}_{5} \mathrm{Cl}$, over a few hours a new ${ }^{1} \mathrm{H}$ NMR resonance at $\delta 8.73$ grew in, the hydride resonance of $\left[\mathrm{HNi}(\mathrm{dmpe})_{2}\right]^{+}$ diminished, and $\left[\mathrm{Ni}(\mathrm{dmpe})_{2}\right]\left[\mathrm{PF}_{6}\right]_{2}$ precipitated. The reaction did not go to completion; the ultimate yield of formate (assessed by integration of NMR spectra) was about 50\%. As the reaction proceeded, the ${ }^{1} \mathrm{H}$ NMR peak attributed to formate gradually shifted upfield $(\delta 8.73$ at $2 \mathrm{~h}, 8.66$ at $18 \mathrm{~h}$ ) while that for the tert-butyl group of the borane shifted downfield ( $\delta$ 0.89 before reaction, 0.95 at $2 \mathrm{~h}, 0.97$ at $18 \mathrm{~h}$ ). Concurrently the ${ }^{11} \mathrm{~B}$ NMR signal shifted upfield ( $\delta 88.2$ before reaction, 65 at $2 \mathrm{~h}, 51$ at $18 \mathrm{~h}$ ) and broadened considerably (Figure 1). Addition of one equivalent of ${ }^{t} \mathrm{Bu}\left(\mathrm{CH}_{2}\right)_{2} \mathrm{~B}\left(\mathrm{C}_{8} \mathrm{H}_{14}\right)$ to $\left[\mathrm{Bu}_{4} \mathrm{~N}\right]\left[\mathrm{HCO}_{2}\right]$ in $\mathrm{C}_{6} \mathrm{D}_{5} \mathrm{Cl}$ shifted the ${ }^{1} \mathrm{H}$ NMR resonance for $\left[\mathrm{HCO}_{2}\right]^{-}$from $\delta 9.58$ to $\delta 8.89$, consistent with some formateborane interaction.

Several other boranes, of varying Lewis acidity, were also examined. Addition of $\mathrm{CO}_{2}$ to a mixture of isopropyl pinacol borane and $\left[\mathrm{HNi}(\mathrm{dmpe})_{2}\right]^{+}$did not significantly increase the amount of formate produced relative to the reaction in the absence of any Lewis acid, although the small ${ }^{1} \mathrm{H}$ NMR signal for $\left[\mathrm{HCO}_{2}\right]^{-}$was shifted upfield ( $\delta 8.74 \mathrm{vs} .8 .84$ without borane). Trimesitylborane also failed to effect significant $\mathrm{CO}_{2}$ reduction, but produced a larger upfield shift ( $\delta 8.63)$, quite similar to that in the trialkylborane reactions. It appears that these formate-borane adducts are considerably less robust, as might be expected for less acidic or more sterically crowded Lewis acids. Triphenylborane did give substantial conversion to formate, but the NMR spectral data indicated formation of unidentified side products as well. The much stronger acid $\mathrm{B}\left(\mathrm{C}_{6} \mathrm{~F}_{5}\right)_{3}$ exhibited only hydride transfer from $\mathrm{Ni}$ to $\mathrm{B}$ and no $\mathrm{CO}_{2}$ reduction.

The results for the trialkylborane, above, clearly indicate formation of a formate-borane adduct (Scheme 6). To further probe this interaction, aliquots of ${ }^{\mathrm{t}} \mathrm{Bu}\left(\mathrm{CH}_{2}\right)_{2} \mathrm{~B}\left(\mathrm{C}_{8} \mathrm{H}_{14}\right)$ were added sequentially to a $\mathrm{C}_{6} \mathrm{D}_{5} \mathrm{Cl}$ solution of formate. Upon addition of borane a second $\left[\mathrm{HCO}_{2}\right]^{-}$signal appeared upfield of the original signal for free formate; the new signal increased in intensity, while the first decreased correspondingly, and both signals broadened and shifted upfield as more borane was added, up to one equivalent. At and beyond one equivalent of borane, only a single sharp resonance was observed, that shifted still further upfield as more borane was added. Addition of 10 equivalents of pyridine caused the peak to shift back to approximately the same position observed after addition of one equivalent of borane, along with substantial broadening. (Spectra are shown in the SI, Figure S15.) These observations appear most consistent with formation of a strong monoborane adduct, $\left[\mathrm{HCC}_{2} \mathrm{BR}_{3}\right]^{-}$, which does not exchange with free $\left[\mathrm{HCO}_{2}\right]^{-}$on the NMR time scale; and a weaker bis(borane) adduct, $\left[\mathrm{HCO}_{2}\left(\mathrm{BR}_{3}\right)_{2}\right]^{-}$, which does rapidly exchange with the mono adduct; only the latter interaction is cleaved by addition of pyridine. This model does not fully explain the NMR behavior, particularly the changing peak shifts below one equivalent of added borane, but we have observed that other factors (such as counterion speciation and precipitation) can have an effect on NMR shifts (the $\left[\mathrm{Bu}_{4} \mathrm{~N}\right]^{+}$resonances also shift with added borane in the above experiment), which could account for these details.

In the absence of any borane, the reaction of $\left[\mathrm{HNi}(\mathrm{dmpe})_{2}\right]\left[\mathrm{PF}_{6}\right]$ with $1 \mathrm{~atm} \mathrm{CO}_{2}$ gave only about $2 \%$ formate product; with borane and the addition of tetraheptylammonium bromide it proceeded to completion, accompanied by precipitation of $\left[\mathrm{Ni}(\mathrm{dmpe})_{2}\right][\mathrm{Br}]_{2}$. Under the 
latter conditions the formate ${ }^{1} \mathrm{H}$ NMR signal ( $\delta$ 8.79) is close to the shift observed for the stoichiometric combination of formate and borane $(\delta 8.89)$.

In an attempt to eliminate some of these complications we investigated $\mathrm{CQ}_{2}$ reduction in acetonitrile, in which all of the constituents are soluble (although there was a concern that $\mathrm{MeCN}$ would bind the borane too tightly to permit any acid assistance). Reaction of $\left[\mathrm{HNi}(\mathrm{dmpe})_{2}\right]\left[\mathrm{PF}_{6}\right]$ with $\mathrm{CO}_{2}$ and no added borane led to $\sim 5 \%$ conversion to $\left[\mathrm{Ni}(\mathrm{dmpe})_{2}\right]^{2+}$ and $\left[\mathrm{HCO}_{2}\right]^{-}\left(\delta 8.40\right.$; c.f. $\left.\left[\mathrm{Bu}_{4} \mathrm{~N}\right]\left[\mathrm{HCO}_{2}\right] \delta 8.68\right)$, while addition of a single equivalent of ${ }^{\mathrm{t}} \mathrm{Bu}\left(\mathrm{CH}_{2}\right)_{2} \mathrm{~B}\left(\mathrm{C}_{8} \mathrm{H}_{14}\right)$ gave $60 \%$ conversion to $\left[\mathrm{HCO}_{2}\left(\mathrm{BR}_{3}\right)_{n}\right]^{-}(\delta 8.29)$, and 10 equiv borane effected essentially complete conversion $(\delta 8.22)$. Addition of one equivalent of $\left[\mathrm{Bu}_{4} \mathrm{~N}\right]\left[\mathrm{HCO}_{2}\right]$ at the end of the last reaction resulted in approximately doubling the peak intensity with a negligible change in position; when the reaction was carried out with one equiv ${ }^{13} \mathrm{CO}_{2}$, the ${ }^{1} \mathrm{H}$ NMR signal at $\delta 8.21$ appeared as a doublet ${ }^{1}\left(J_{\mathrm{CH}}=202 \mathrm{~Hz}\right)$, and a new intense ${ }^{13} \mathrm{C}\left\{{ }^{1} \mathrm{H}\right\}$ NMR signal appeared at $\delta$ 174.16. These findings establish conclusively that the signal around $\delta 8.2$ is indeed due to formate generated by reduction of $\mathrm{CO}_{2}$. The ${ }^{11} \mathrm{~B}$ NMR resonance of the free borane in $\mathrm{CD}_{3} \mathrm{CN}$ is far upfield from that in $\mathrm{C}_{6} \mathrm{D}_{5} \mathrm{Cl}$, consistent with formation of a $\mathrm{CD}_{3} \mathrm{CN}$ adduct; that must be weaker than the formate-borane adduct, however, since the ${ }^{11} \mathrm{~B}$ NMR resonance shifts further upfield (by $\sim 3$ $\mathrm{ppm}$ ) as formate is produced.

In principle reduction of $\mathrm{CO}_{2}$ by $\mathrm{H}_{2}$ could be made catalytic in nickel, by employing a suitable base in concert with $\left[\mathrm{Ni}(\mathrm{dmpe})_{2}\right]^{2+}$ to cleave $\mathrm{H}_{2},{ }^{12 \mathrm{c}}$ followed by hydride delivery to $\mathrm{CO}_{2}$ (Scheme 7). The base must be of sufficient steric bulk to inhibit strong adduct formation with the borane and/or nucleophilic attack at $\mathrm{CO}_{2}$. When a mixture of [Ni(dmpe $\left.)_{2}\right]^{2+}, 5$ equiv $\mathrm{NEt}_{3}$, and 5 equiv ${ }^{t} \mathrm{Bu}\left(\mathrm{CH}_{2}\right)_{2} \mathrm{~B}\left(\mathrm{C}_{8} \mathrm{H}_{14}\right)$ in $\mathrm{CD}_{3} \mathrm{CN}$ was exposed to $\mathrm{H}_{2} / \mathrm{CO}_{2}$ (1 atm of a 1:1 mixture), slow conversion to small amounts of formate $(\sim 8 \%$ relative to $\mathrm{Ni}$ ) was observed over 3 days. The slow reaction is due (at least in part) to slow formation of $\left[\mathrm{HNi}(\mathrm{dmpe})_{2}\right]^{+}$under these conditions: a solution of $\left[\mathrm{Ni}(\mathrm{dmpe})_{2}\right]\left[\mathrm{PF}_{6}\right]_{2}$ and $\mathrm{NEt}_{3}$ (4 equiv) in $\mathrm{CD}_{3} \mathrm{CN}$ under 1 atm $\mathrm{H}_{2}$ was only $30 \%$ converted to [ $\left.\mathrm{HNi}(\mathrm{dmpe})_{2}\right]\left[\mathrm{PF}_{6}\right.$ ] after 3 days.

In contrast, the reaction of $\left[\mathrm{Ni}(\mathrm{dmpe})_{2}\right]\left[\mathrm{BAr}_{4}\right]_{2}\left(\mathrm{BAr}_{4}=\right.$ tetrakis $(3,5-$ trifluoromethylphenyl)borate) and $\mathrm{NEt}_{3}$ with $\mathrm{H}_{2}$ proceeded far faster in $\mathrm{C}_{6} \mathrm{D}_{5} \mathrm{Cl}$, with high conversion to $\left[\mathrm{HNi}(\mathrm{dmpe})_{2}\right]^{+}$in 3 hours, and full conversion after 18 hours. We ascribe the difference to coordination of solvent (Scheme 8$)$ : the adduct $\left[\mathrm{Ni}(\mathrm{dmpe})_{2}(\mathrm{MeCN})\right]^{2+}$ has been structurally characterized, and its formation constant estimated by electrochemical techniques as $K_{e q}=0.3$, whereas in chlorobenzene $\left[\mathrm{Ni}(\mathrm{dmpe})_{2}\right]^{2+}$ would be present as the 4coordinate square planar complex (whose structure has also been determined). ${ }^{12 a}$ Counteranion effects appear to be unimportant: $\left[\mathrm{Ni}(\mathrm{dmpe})_{2}\right]\left[\mathrm{BAr}^{\mathrm{F}}\right]_{2}$ reacts at roughly the same rate as $\left[\mathrm{Ni}(\mathrm{dmpe})_{2}\right]\left[\mathrm{PF}_{6}\right]_{2}$ with $\mathrm{NEt}_{3}$ under $\mathrm{H}_{2}$ in $\mathrm{CD}_{3} \mathrm{CN}$.

Disappointingly, a solution of $\left[\mathrm{Ni}(\mathrm{dmpe})_{2}\right]\left[\mathrm{BAr}_{4}\right]_{2},{ }^{t} \mathrm{Bu}\left(\mathrm{CH}_{2}\right)_{2} \mathrm{~B}\left(\mathrm{C}_{8} \mathrm{H}_{14}\right)$ and $\mathrm{NEt}_{3}$ under $\mathrm{H}_{2} / \mathrm{CO}_{2}$ in $\mathrm{C}_{6} \mathrm{D}_{5} \mathrm{Cl}$ did not produce any detectable formate, despite the steady growth of $\left[\mathrm{HNi}(\mathrm{dmpe})_{2}\right]^{+}$over a few days. It is unclear why no formate is generated. Reactions in $\mathrm{CD}_{2} \mathrm{Cl}_{2}$ led to formation of $\mathrm{CD}_{2} \mathrm{HCl}$, indicating a hydride transfer side reaction.

Reduction of $\mathrm{CO}_{2}$ with $\mathrm{H}_{2}$ could, however, be achieved with the rhodium cation $\left[\mathrm{Rh}(\mathrm{dmpe})_{2}\right][\mathrm{OTf}]$ - without the need for an added base, since its $\mathrm{H}_{2}$ oxidative addition product, $\left[\mathrm{H}_{2} \mathrm{Rh}(\mathrm{dmpe})_{2}\right][\mathrm{OTf}]$, is a hydride donor of strength $\left(\Delta G_{\mathrm{H}_{-}}=50.4 \mathrm{kcal} \mathrm{mol}^{-}\right)^{13}$ similar to that of $\left[\mathrm{HNi}(\mathrm{dmpe})_{2}\right]^{+}$. Treatment of $\left[\mathrm{Rh}(\mathrm{dmpe})_{2}\right][\mathrm{OTf}]$ with $\mathrm{H}_{2} / \mathrm{CO}_{2}(1 \mathrm{~atm}$ of a 1:1 mixture) in $\mathrm{CD}_{3} \mathrm{CN}$ led to formation of some $\left[\mathrm{H}_{2} \mathrm{Rh}(\mathrm{dmpe})_{2}\right]$ [OTf] but no formate over 4 days; however, inclusion of ${ }^{t} \mathrm{Bu}\left(\mathrm{CH}_{2}\right)_{2} \mathrm{~B}\left(\mathrm{C}_{8} \mathrm{H}_{14}\right)$ in the reaction led to the generation of formate ( ${ }^{1} \mathrm{H}$ NMR signal at $\left.\delta 8.24\right)$ along with the Rh product of hydride transfer, 
$\left[\mathrm{HRh}(\mathrm{dmpe})_{2}(\mathrm{MeCN})\right]^{2+}$, over a few hours (Scheme 9). With one equivalent of trialkylborane, the yield of formate was $\sim 25 \%$ (by NMR integration). Some $\left[\mathrm{Rh}(\mathrm{dmpe})_{2}\right]^{+}$ remained unconverted during the course of the reaction, consistent with the unfavorable thermodynamics of $\mathrm{H}_{2}$ oxidative addition (uphill by $\left.0.44 \mathrm{kcal} \mathrm{mol}^{-1}\right)^{13}$ and the low $(\sim 0.5$ atm) $\mathrm{H}_{2}$ pressure; $1 \mathrm{~atm} \mathrm{H}_{2}$ is required for complete conversion.

\section{Conclusions}

The late transition metal bis(diphosphine) hydride complexes $\left[\mathrm{HNi}(\mathrm{dmpe})_{2}\right]^{+}$and $\left[\mathrm{H}_{2} \mathrm{Rh}(\mathrm{dmpe})_{2}\right]^{+}$(as well as a rhenium-boroxycarbene complex) are able to reduce carbon dioxide to formate, with the assistance of a trialkylborane that shifts the otherwise unfavorable equilibrium by forming a formate-borane adduct. Furthermore, $\mathrm{H}_{2}$ can be used directly in these systems to reduce $\mathrm{CO}_{2}$. As judged by NMR spectroscopy, the formateborane adduct is relatively weak (in comparison to those generated in the $\mathrm{CO}$ reductions studied previously) and hence might be broken sufficiently easily to close a catalytic cycle. While overall catalysis has so far eluded us, the prospects for developing catalytic systems based on this chemistry appear promising.

\section{Experimental Section}

\section{General Considerations}

All air- and moisture-sensitive compounds were manipulated using standard vacuum line or Schlenk techniques, or in a glovebox under a nitrogen atmosphere. All reactions were carried out in an inert atmosphere, unless otherwise noted. Under standard glovebox conditions, petroleum ether, diethyl ether, benzene, toluene, and tetrahydrofuran were used without purging, such that traces of those solvents were in the atmosphere, and could be found intermixed in the solvent bottles. The solvents for air- and moisture-sensitive reactions were dried over sodium benzophenone ketyl, calcium hydride, or by the method of Grubbs. ${ }^{14}$ All NMR solvents were purchased from Cambridge Isotopes Laboratories, Inc. Chlorobenzene- $\mathrm{d}_{5}\left(\mathrm{C}_{6} \mathrm{D}_{5} \mathrm{Cl}\right)$ and dichloromethane- $\mathrm{d}_{2}\left(\mathrm{CD}_{2} \mathrm{Cl}_{2}\right)$ were freeze-pump-thaw degassed three times before being run through a small column of activated alumina. Tetrahydrofuran- $\mathrm{d}_{8}\left(\mathrm{THF}-\mathrm{d}_{8}\right)$ was purchased in a sealed ampoule, and dried by passage through activated alumina. Unless noted, other materials were used as received. [1] $\left[\mathrm{BF}_{4}\right],{ }^{2 \mathrm{a}} 2,\left[\mathrm{Pt}(\mathrm{dmpe})_{2}\right]\left[\mathrm{PF}_{6}\right]_{2},{ }^{15}\left[\mathrm{HPt}(\mathrm{dmpe})_{2}\right]\left[\mathrm{PF}_{6}\right],{ }^{15}\left[\mathrm{Ni}(\mathrm{dmpe})_{2}\right]\left[\mathrm{BF}_{4}\right]_{2},{ }^{12 \mathrm{a}}\left[\mathrm{HNi}(\mathrm{dmpe})_{2}\right]$ $\left[\mathrm{PF}_{6}\right],{ }^{15 \mathrm{t}} \mathrm{Bu}\left(\mathrm{CH}_{2}\right)_{2} \mathrm{~B}\left(\mathrm{C}_{8} \mathrm{H}_{14}\right),{ }^{16}\left[\mathrm{Bu}_{4} \mathrm{~N}\right]\left[\mathrm{HCO}_{2}\right],{ }^{17}\left[\mathrm{Ni}(\mathrm{dmpe})_{2}\right]\left[\mathrm{BAr}{ }_{4}\right]_{2},{ }^{2 \mathrm{c}}$ and $\left[\mathrm{Rh}(\mathrm{dmpe})_{2}\right]$ $[\mathrm{OTf}]^{13},{ }^{18}$ were synthesized by literature methods. All other materials were readily commercially available, and used as received. ${ }^{1} \mathrm{H}$ and ${ }^{13} \mathrm{C}$ NMR spectra were recorded on Varian Mercury $300 \mathrm{MHz}, 400-\mathrm{MR} 400 \mathrm{MHz}$, INOVA $500 \mathrm{MHz}$, or INOVA $600 \mathrm{MHz}$ spectrometers at room temperature, unless indicated otherwise. Chemical shifts are reported with respect to residual internal protio solvent for ${ }^{1} \mathrm{H}$ and ${ }^{13} \mathrm{C}\left\{{ }^{1} \mathrm{H}\right\}$ spectra. Other nuclei were referenced to an external standard: $\mathrm{H}_{3} \mathrm{PO}_{4}\left({ }^{31} \mathrm{P}\right), 15 \% \mathrm{BF}_{3} \cdot \mathrm{Et}_{2} \mathrm{O} / \mathrm{CDCl}_{3}\left({ }^{11} \mathrm{~B}\right), \mathrm{CFCl}_{3}$ $\left({ }^{19} \mathrm{~F}\right)$, all at $0 \mathrm{ppm}$.

\section{Experimental Procedures}

\section{$\mathrm{CO}_{2}$ reduction involving rhenium carbonyl complexes}

Reaction of 2 with $\mathrm{CO}_{2}-\mathrm{A} 10 \mathrm{~mL}$ vial was charged with $26.4 \mathrm{mg}(0.0251 \mathrm{mmol})$ [1] $\left[\mathrm{BF}_{4}\right]$ and $\sim 0.6 \mathrm{~mL} \mathrm{C}_{6} \mathrm{D}_{5} \mathrm{Cl}$. With stirring, $25.1 \mu \mathrm{L}\left(0.0251 \mathrm{mmol}^{2} \mathrm{NaHBEt}_{3}(1.0 \mathrm{M}\right.$ in toluene) was added dropwise to provide a pale yellow solution. The reaction mixture was transferred to a J-Young NMR tube and initial spectroscopic measurements showed clean conversion to boroxycarbene 2 . The tube was placed under vacuum for 1 minute with gentle shaking to degas, and one atmosphere of $\mathrm{CO}_{2}$ was then admitted to the tube. NMR 
spectroscopy after 5 minutes showed complete conversion to $\mathbf{1} \cdot\left(\mathrm{HCO}_{2}\right)$, most of which precipitated overnight. ${ }^{1} \mathbf{H}$ NMR $\left(\mathrm{C}_{6} \mathrm{D}_{5} \mathrm{Cl}, 500 \mathrm{MHz}\right)$ : toluene and $\mathrm{BEt}_{3}$ are omitted, but overlap with some aliphatic peaks, preventing good integration. $\delta 0.69(\mathrm{br} \mathrm{s}, 4 \mathrm{H}), 1.59(\mathrm{br} \mathrm{s}$, overlapping), 1.84 (br, overlapping), 2.05 (br m, overlapping), 2.73 (br, 4H), 7.41 (br, 12H), $8.45\left(\mathrm{~s}, 1 \mathrm{H}, \mathrm{HCO}_{2}{ }^{-}\right) \cdot{ }^{31} \mathbf{P}\left\{{ }^{1} \mathbf{H}\right\} \mathbf{N M R}\left(\mathrm{C}_{6} \mathrm{D}_{5} \mathrm{Cl}, 121 \mathrm{MHz}\right): \delta 2.2 . \mathbf{I R}\left(\mathrm{C}_{6} \mathrm{D}_{5} \mathrm{Cl}\right): v_{\mathrm{co}} 1993$, $1620 \mathrm{~cm}^{-1} \cdot{ }^{13} \mathrm{C}$ NMR spectra could not be acquired because of the low solubility of the product.

Reaction of [1][BF $\left.{ }_{4}\right]$ with $\left[\mathrm{Bu}_{4} \mathrm{~N}\right]\left[\mathrm{HCO}_{2}\right]-\mathrm{A} \mathrm{J}$-Young NMR tube was charged with $29.1 \mathrm{mg}(0.0276 \mathrm{mmol})[\mathbf{1}]\left[\mathrm{BF}_{4}\right], 7.9 \mathrm{mg}(0.0276 \mathrm{mmol})\left[\mathrm{Bu}_{4} \mathrm{~N}\right]\left[\mathrm{HCO}_{2}\right]$, and $\sim 0.6 \mathrm{~mL}$ $\mathrm{C}_{6} \mathrm{D}_{5} \mathrm{Cl}$. After 15 minutes, ${ }^{1} \mathrm{H}$ and ${ }^{31} \mathrm{P}\left\{{ }^{1} \mathrm{H}\right\}$ NMR spectroscopy showed essentially complete conversion to 1-( $\left(\mathrm{HCO}_{2}\right)$. After about 30 minutes some precipitates were observed, and precipitation of white solids continued over the next 3 hours. At this time, the solution was decanted, and IR spectroscopy showed resonances that matched the preparation of $\mathbf{1} \cdot\left(\mathrm{HCO}_{2}\right)$ from $\mathrm{CO}_{2}$; an additional peak at $1660 \mathrm{~cm}^{-1}$ is unidentified, however. ${ }^{1} \mathbf{H} \mathbf{~ N M R}\left(\mathrm{C}_{6} \mathrm{D}_{5} \mathrm{Cl}\right.$, $400 \mathrm{MHz}):\left[\mathrm{Bu}_{4} \mathrm{~N}\right]^{+}$peaks omitted. $\delta 0.68(\mathrm{br}, 4 \mathrm{H}), 0.95(\mathrm{br}, 4 \mathrm{H}), 1.58(\mathrm{br}, 4 \mathrm{H}), 1.83(\mathrm{br}$, $16 \mathrm{H}), 2.03(\mathrm{br}, 4 \mathrm{H}), 2.75(\mathrm{br}, 4 \mathrm{H}), 7.1-7.2(\mathrm{~m}, 12 \mathrm{H}), 7.4(\mathrm{~m}, 8 \mathrm{H}), 8.49(\mathrm{~s}, 1 \mathrm{H}$, $\left.\left[\mathrm{HCO}_{2}\right]^{-}\right) .{ }^{31} \mathbf{P}\left\{{ }^{1} \mathbf{H}\right\}$ NMR $\left(\mathrm{C}_{6} \mathrm{D}_{5} \mathrm{Cl}, 162 \mathrm{MHz}\right): \delta 2.4 . \mathbf{I R}\left(\mathrm{C}_{6} \mathrm{D}_{5} \mathrm{Cl}\right): v_{\mathrm{co}} 1993,1660,1621$ $\mathrm{cm}^{-1}$.

Reaction of [1][BF 4 and [HNi(dmpe) $\left.)_{2}\right]\left[\mathrm{PF}_{6}\right]$ with $\mathrm{CO}_{2}$ in $\mathrm{C}_{6} \mathrm{D}_{5} \mathrm{Cl}-\mathrm{A} \mathrm{J}$-Young NMR tube was charged with $24.3 \mathrm{mg}(0.0231 \mathrm{mmol})$ [1] $\left[\mathrm{BF}_{4}\right], 11.6 \mathrm{mg}(0.0231 \mathrm{mmol})$ $\left[\mathrm{HNi}(\mathrm{dmpe})_{2}\right]\left[\mathrm{PF}_{6}\right]$, and $\sim 0.6 \mathrm{~mL} \mathrm{C}_{6} \mathrm{D}_{5} \mathrm{Cl}$. The tube was sealed and initial NMR spectroscopic measurements showed no reaction. 1 atm $\mathrm{CO}_{2}$ was added; after $\sim 20$ minutes some formate was observed, which grew in over a few hours. During this time precipitates formed, and after about 12 hours there was essentially no formate-containing product in solution. The solids were collected, washed with $\mathrm{CD}_{3} \mathrm{CN}$ (to extract $\left[\mathrm{Ni}(\mathrm{dmpe})_{2}\right]\left[\mathrm{PF}_{6}\right]_{2}$ ) and $\mathrm{C}_{6} \mathrm{D}_{5} \mathrm{Cl}$, and treated with $\mathrm{C}_{6} \mathrm{D}_{5} \mathrm{Cl}$ containing $3.8 \mu \mathrm{L}$ (0.0462 mmol, 2 equiv) pyridine, which dissolved most of the solids. An asymmetric product was observed by NMR spectroscopy which was assigned as $\mathbf{1} \cdot\left(\mathrm{HCO}_{2}\right)$ (pyridine). ${ }^{1} \mathbf{H} \mathbf{~ N M R}\left(\mathrm{C}_{6} \mathrm{D}_{5} \mathrm{Cl}, 300 \mathrm{MHz}\right): \delta 0.44$ (br, $2 \mathrm{H}$, $\mathrm{Ph}_{2} \mathrm{PCH}_{2} \mathrm{CH}_{2} \mathrm{BR}_{2}$ ), 0.68 (br, $2 \mathrm{H}, \mathrm{Ph}_{2} \mathrm{PCH}_{2} \mathrm{CH}_{2} \mathrm{BR}_{2}$ ), 0.95 ( $2 \mathrm{H}, \mathrm{Ph}_{2} \mathrm{PCH}_{2} \mathrm{CH}_{2} \mathrm{BR}$ ), 1.09 $\left(2 \mathrm{H}, \mathrm{Ph}_{2} \mathrm{PCH}_{2} \mathrm{CH}_{2} \mathrm{~B} R_{2}\right), 1.34\left(6 \mathrm{H}, \mathrm{Ph}_{2} \mathrm{PCH}_{2} \mathrm{CH}_{2} \mathrm{~B} R_{2}\right), 1.5-2.0(\mathrm{~m}, 18 \mathrm{H}$, $\mathrm{Ph}_{2} \mathrm{PCH}_{2} \mathrm{CH}_{2} \mathrm{~B} R_{2}$ ), 2.1 (br, $4 \mathrm{H}, \mathrm{Ph}_{2} \mathrm{PCH}_{2} \mathrm{CH}_{2} \mathrm{BR} R_{2}$ ), 2.47 (br, $2 \mathrm{H}, \mathrm{Ph}_{2} \mathrm{PCH}_{2} \mathrm{CH}_{2} \mathrm{~B} R_{2}$ ), 2.93 (m, 2H, $\left.\mathrm{Ph}_{2} \mathrm{PCH}_{2} \mathrm{CH}_{2} \mathrm{~B} R_{2}\right), 6.5-7.5$ (m, mixture of $\mathrm{Ph}_{2} \mathrm{PR}$, free and bound $\left.\mathrm{C}_{6} \mathrm{H}_{5} \mathrm{~N}\right), 8.41$ $\left(\mathrm{m}, 2 \mathrm{H}, \mathrm{C}_{6} H_{5} \mathrm{~N}\right), 8.88\left(1 \mathrm{H}, \mathrm{HCO}_{2}\right) .{ }^{31} \mathbf{P}\left\{{ }^{1} \mathbf{H}\right\} \mathbf{N M R}\left(\mathrm{C}_{6} \mathrm{D}_{5} \mathrm{Cl}, 121 \mathrm{MHz}\right): \delta 1.95\left(\mathrm{~d}, J_{\mathrm{PP}}=77\right.$ $\mathrm{Hz}), 2.98\left(\mathrm{~d}, J_{\mathrm{PP}}=76 \mathrm{~Hz}\right)$.

\section{$\mathrm{CO}_{2}$ reduction by nickel and boranes in chlorobenzene}

Reaction of $\left[\mathrm{HNi}(\mathrm{dmpe})_{2}\right]\left[\mathrm{PF}_{6}\right.$ ] with $\mathrm{CO}_{2}-\mathrm{A} \mathrm{J}$-Young NMR tube was charged with $12.2 \mathrm{mg}(0.0242 \mathrm{mmol})\left[\mathrm{HNi}(\mathrm{dmpe})_{2}\right]\left[\mathrm{PF}_{6}\right]$ and $\sim 0.6 \mathrm{~mL} \mathrm{C}_{6} \mathrm{D}_{5} \mathrm{Cl}$. The tube was degased by exposure to vacuum briefly with gentle shaking, and $1 \mathrm{~atm} \mathrm{CO}_{2}$ was admitted to the tube. The tube was sealed, shaken well, and monitored by NMR spectroscopy. A small resonance assigned to formate was observed at $\delta 8.84$, integrating $1-2 \%$ relative to the Ni hydride. No increase in the formate resonance was observed over 48 hours.

Reaction of $\left[\mathrm{HNi}(\mathrm{dmpe})_{2}\right]\left[\mathrm{PF}_{6}\right]$ with ${ }^{t} \mathrm{Bu}\left(\mathrm{CH}_{2}\right)_{2} \mathrm{~B}\left(\mathrm{C}_{8} \mathrm{H}_{14}\right)$ and $\mathrm{CO}_{2}$-A solution of $6.7 \mathrm{mg}(0.0327 \mathrm{mmol}){ }^{t} \mathrm{Bu}\left(\mathrm{CH}_{2}\right)_{2} \mathrm{~B}\left(\mathrm{C}_{8} \mathrm{H}_{14}\right)$ in $\sim 0.6 \mathrm{~mL} \mathrm{C}_{6} \mathrm{D}_{5} \mathrm{Cl}$ was added to $16.5 \mathrm{mg}$ $(0.0327 \mathrm{mmol})$ solid $\left[\mathrm{HNi}(\mathrm{dmpe})_{2}\right]\left[\mathrm{PF}_{6}\right]$. The reaction mixture was transferred to a J-Young NMR tube, and initial spectroscopic measurements were made. After two freeze-pumpthaw cycles, $1 \mathrm{~atm} \mathrm{CO}_{2}$ was admitted to the tube, and the reaction was monitored by NMR spectroscopy. After 24 hours the reaction had reached partial conversion (with the formate resonance shifting from $\delta 8.73$ to 8.66 ), which did not change over 4 days. Addition of $\sim 16.0$ 
$\mathrm{mg}\left(0.0327 \mathrm{mmol}, 1\right.$ equiv nominal; about 2 equiv by NMR integration) [hept $\left.{ }_{4} \mathrm{~N}\right][\mathrm{Br}]$ led to significant further growth of $\left[\right.$ hept $\left.{ }_{4} \mathrm{~N}\right]\left[\mathrm{HCO}_{2}\left(\mathrm{BR}_{3}\right)_{\mathrm{n}}\right]$, which (along with excess [hept $\left.\mathrm{H}_{4} \mathrm{~N}\right]$ $[\mathrm{Br}]$ ) was the only soluble product (all hydride was consumed). The spectra agreed well with independently synthesized $\left[\mathrm{Bu}_{4} \mathrm{~N}\right]\left[\mathrm{HCO}_{2}\left(\mathrm{BR}_{3}\right)_{\mathrm{n}}\right]$ (see below). ${ }^{\mathbf{1}} \mathbf{H} \mathbf{N M R}\left(\mathrm{C}_{6} \mathrm{D}_{5} \mathrm{Cl}, 400\right.$ $\mathrm{MHz}): \delta 0.78\left(\mathrm{~m}, 2 \mathrm{H},{ }^{t} \mathrm{BuCH}_{2} \mathrm{CH}_{2} \mathrm{~B}\left(\mathrm{C}_{8} \mathrm{H}_{14}\right)\right), 0.88\left(\mathrm{t}, \mathrm{J}=6.8 \mathrm{~Hz},\left[\mathrm{hept}_{4} \mathrm{~N}\right]^{+}\right), 1.04(\mathrm{~s}$, $9 \mathrm{H},{ }^{t} \mathrm{BuCH}_{2} \mathrm{CH}_{2} \mathrm{~B}\left(\mathrm{C}_{8} \mathrm{H}_{14}\right)$ ), $\left.1.1\left(\mathrm{br}, 2 \mathrm{H},{ }^{t} \mathrm{BuCH}_{2} \mathrm{CH}_{2} \mathrm{~B}\left(\mathrm{C}_{8} \mathrm{H}_{14}\right) \text { ), 1.2-1.3 (br m, [hept }{ }_{4} \mathrm{~N}\right]^{+}\right)$, $\left.1.39\left(\mathrm{~m}, 2 \mathrm{H},{ }^{t} \mathrm{BuCH}_{2} \mathrm{CH}_{2} \mathrm{~B}\left(\mathrm{C}_{8} \mathrm{H}_{14}\right)\right), 1.5\left(\mathrm{br} \text {, [hept }{ }_{4} \mathrm{~N}\right]^{+}\right), 1.76$ (br, $\left.2 \mathrm{H},{ }^{t} \mathrm{BuCH}_{2} \mathrm{CH}_{2} \mathrm{~B}\left(\mathrm{C}_{8} \mathrm{H}_{14}\right)\right), 1.94$ (br, $\left.4 \mathrm{H},{ }^{t} \mathrm{BuCH}_{2} \mathrm{CH}_{2} \mathrm{~B}\left(\mathrm{C}_{8} \mathrm{H}_{14}\right)\right), 2.2$ (br, $\left.6 \mathrm{H},{ }^{t} \mathrm{BuCH}_{2} \mathrm{CH}_{2} \mathrm{~B}\left(\mathrm{C}_{8} \mathrm{H}_{14}\right)\right), 3.11\left(\mathrm{~m}\right.$, $\left.\left[\mathrm{hept}_{4} \mathrm{~N}\right]^{+}\right), 8.83\left(1 \mathrm{H},\left[\mathrm{HCO}_{2}\left(\mathrm{BR}_{3}\right)_{\mathrm{n}}\right]^{-}\right)$. No discernible signals were observed by ${ }^{11} \mathrm{~B}$ NMR spectroscopy, presumably due to broadening and overlapping with the borosilicate glass in the probe construction.

Reaction of $\left[\mathrm{Bu}_{4} \mathrm{~N}\right]\left[\mathrm{HCO}_{2}\right]$ with ${ }^{t} \mathrm{Bu}\left(\mathrm{CH}_{2}\right)_{2} \mathrm{~B}\left(\mathrm{C}_{8} \mathrm{H}_{14}\right)$ in $\mathrm{C}_{6} \mathrm{D}_{5} \mathrm{Cl}$-A J-Young NMR tube was charged with $15.8 \mathrm{mg}(0.0549 \mathrm{mmol})\left[\mathrm{Bu}_{4} \mathrm{~N}\right]\left[\mathrm{HCO}_{2}\right], 11.3 \mathrm{mg}(0.0549$ $\mathrm{mmol}){ }^{t} \mathrm{Bu}\left(\mathrm{CH}_{2}\right)_{2} \mathrm{~B}\left(\mathrm{C}_{8} \mathrm{H}_{14}\right)$, and $\sim 0.6 \mathrm{~mL} \mathrm{C}_{6} \mathrm{D}_{5} \mathrm{Cl}$. NMR spectroscopy revealed a formate resonance at $\delta 8.89$, well upfield of $\left[\mathrm{Bu}_{4} \mathrm{~N}\right]\left[\mathrm{HCO}_{2}\right]$ in the absence of borane $(\delta 9.58) .{ }^{1} \mathbf{H}$ NMR $\left(\mathrm{C}_{6} \mathrm{D}_{5} \mathrm{Cl}, 500 \mathrm{MHz}\right): \delta 0.76\left(\mathrm{~m},{ }^{t} \mathrm{BuCH}_{2} \mathrm{CH}_{2} \mathrm{~B}\left(\mathrm{C}_{8} \mathrm{H}_{14}\right), 2 \mathrm{H}\right), 0.86(\mathrm{t}, \mathrm{J}=7.3 \mathrm{~Hz}$, $\left.\mathrm{N}\left(\mathrm{CH}_{2} \mathrm{CH}_{2} \mathrm{CH}_{2} \mathrm{CH}_{3}\right)_{4}, 12 \mathrm{H}\right), 1.04\left(\mathrm{~s},{ }^{t}{ }^{B} u \mathrm{CH}_{2} \mathrm{CH}_{2} \mathrm{~B}\left(\mathrm{C}_{8} \mathrm{H}_{14}\right), 9 \mathrm{H}\right), 1.25$ (q, J = $7.2 \mathrm{~Hz}$, $\left.\mathrm{N}\left(\mathrm{CH}_{2} \mathrm{CH}_{2} \mathrm{CH}_{2} \mathrm{CH}_{3}\right)_{4}, 8 \mathrm{H}\right), 1.4\left(\mathrm{~m}, 10 \mathrm{H}, \mathrm{N}\left(\mathrm{CH}_{2} \mathrm{CH}_{2} \mathrm{CH}_{2} \mathrm{CH}_{3}\right)_{4}\right.$ and ${ }^{t} \mathrm{BuCH}_{2} \mathrm{CH}_{2} \mathrm{~B}\left(\mathrm{C}_{8} \mathrm{H}_{14}\right)$ overlapping), 1.83 (br, $\left.{ }^{t} \mathrm{BuCH}_{2} \mathrm{CH}_{2} \mathrm{~B}\left(\mathrm{C}_{8} \mathrm{H}_{14}\right), 2 \mathrm{H}\right), 1.97$ (br, ${ }^{t} \mathrm{BuCH}_{2} \mathrm{CH}_{2} \mathrm{~B}\left(\mathrm{C}_{8} \mathrm{H}_{14}\right), 4 \mathrm{H}$ ), 2.28 (br, $\left.{ }^{t} \mathrm{BuCH}_{2} \mathrm{CH}_{2} \mathrm{~B}\left(\mathrm{C}_{8} \mathrm{H}_{14}\right), 6 \mathrm{H}\right), 3.00\left(\mathrm{~m}, \mathrm{~N}\left(\mathrm{CH}_{2} \mathrm{CH}_{2} \mathrm{CH}_{2} \mathrm{CH}_{3}\right)_{4}\right), 8.89$ (s, $\left.\left.\left[\mathrm{HCO}_{2}\left(\mathrm{BR}_{3}\right)_{\mathrm{n}}\right]-1 \mathrm{H}\right) .{ }^{13} \mathbf{C}_{\mathbf{1}}{ }^{1} \mathbf{H}\right\} \mathbf{~ N M R}\left(\mathrm{C}_{6} \mathrm{D}_{5} \mathrm{Cl}, 126 \mathrm{MHz}\right): \delta$ 13.66, 19.87, 23.91, 26.80, 30.05, 31.35, 33.0 (br), 40.75, 58.66, 168.48. ${ }^{11} \mathbf{B}$ NMR $\left(\mathrm{C}_{6} \mathrm{D}_{5} \mathrm{Cl}, 160 \mathrm{MHz}\right): \delta 2.7$.

Titration of $\left[\mathrm{Bu}_{4} \mathrm{~N}\right]\left[\mathrm{HCO}_{2}\right]$ with ${ }^{t} \mathrm{Bu}\left(\mathrm{CH}_{2}\right)_{2} \mathrm{~B}\left(\mathrm{C}_{8} \mathrm{H}_{14}\right)$ in $\mathrm{C}_{6} \mathrm{D}_{5} \mathrm{Cl}-\mathrm{A}$ J-Young NMR tube was charged with $22.1 \mathrm{mg}(0.0769 \mathrm{mmol})\left[\mathrm{Bu}_{4} \mathrm{~N}\right]\left[\mathrm{HCO}_{2}\right]$ and $0.600 \mathrm{~mL} \mathrm{C}_{6} \mathrm{D}_{5} \mathrm{Cl}$. Initial NMR spectra were collected. A $1.0 \mathrm{M}$ solution of ${ }^{t} \mathrm{Bu}\left(\mathrm{CH}_{2}\right)_{2} \mathrm{~B}\left(\mathrm{C}_{8} \mathrm{H}_{14}\right)$ in $\mathrm{C}_{6} \mathrm{D}_{5} \mathrm{Cl}$ was prepared, and $\sim 19 \mu \mathrm{L}(\sim 0.25$ equiv) was added by syringe, followed by collection of NMR spectra. Integration showed that 0.20 equiv was added. This procedure was repeated so that spectra with $0,0.2,0.75,1.5,2.4,3.4,5.1$, and 7.0 equiv borane (by NMR integration) were obtained. Spectra are shown in the SI as Figure S15.

\section{General procedure for reactions of $\left[\mathrm{HNi}(\mathrm{dmpe})_{2}\right]\left[\mathrm{PF}_{6}\right]$ with $\mathrm{CO}_{2}$ and other}

boranes-A solution of borane $(\sim 0.03 \mathrm{mmol})$ in $\sim 0.6 \mathrm{~mL} \mathrm{C}_{6} \mathrm{D}_{5} \mathrm{Cl}$ was added to an equimolar amount of solid $\left[\mathrm{HNi}(\mathrm{dmpe})_{2}\right]\left[\mathrm{PF}_{6}\right]$. The reaction mixture was transferred to a $\mathrm{J}$ Young NMR tube, and initial spectroscopic measurements were made. After two freezepump-thaw cycles, $1 \mathrm{~atm} \mathrm{CO}_{2}$ was admitted to the tube, and the reaction was monitored by NMR spectroscopy.

Isopropyl pinacol borate-The reaction proceeded essentially the same as that with no borane added. The formate resonance appears between $\delta 8.70$ and 8.74 during the reaction.

Triphenylborane-Complete disappearance of $\left[\mathrm{HNi}(\mathrm{dmpe})_{2}\right]^{+}$was observed, along with appearance of a presumed formate resonance at $\delta 8.8$ and some unidentified peaks ( $\delta 5-6)$.

Trimesitylborane-No change in conversion was observed as compared to the reaction without borane. A minor formate resonance was observed at $\delta 8.63$.

$\mathbf{B}\left(\mathbf{C}_{6} \mathbf{F}_{5}\right)_{3}$ - Shortly after mixing $\mathrm{B}\left(\mathrm{C}_{6} \mathrm{~F}_{5}\right)_{3}$ and $\left[\mathrm{HNi}(\mathrm{dmpe})_{2}\right]\left[\mathrm{PF}_{6}\right]$, a mixture of $\left[\mathrm{Ni}(\mathrm{dmpe})_{2}\right]^{2+}$ and $\left[\mathrm{HNi}(\mathrm{dmpe})_{2}\right]^{+}$was observed by ${ }^{1} \mathrm{H}$ NMR spectroscopy. ${ }^{19} \mathrm{~F}$ and ${ }^{11} \mathrm{~B}$ NMR showed complete consumption of $\mathrm{B}\left(\mathrm{C}_{6} \mathrm{~F}_{5}\right)_{3}$ and were consistent with formation of a 4-coordinate borate. The observed ${ }^{11} \mathrm{~B}$ NMR resonance is slightly downfield from the 
expected chemical shift of $\left[\mathrm{HE}\left(\mathrm{C}_{6} \mathrm{~F}_{5}\right)_{3}\right]^{-}$and the resonance is broadened beyond being able to observe coupling (probably due to exchange with some free borane). Even after $\mathrm{CO}_{2}$ addition, no formate was observed after $\sim 12$ hours at room temperature. ${ }^{1} \mathbf{H} \mathbf{N M R}\left(\mathrm{C}_{6} \mathrm{D}_{5} \mathrm{Cl}\right.$, $500 \mathrm{MHz}): \delta-14.40\left(\left[\mathrm{HNi}(\mathrm{dmpe})_{2}\right]^{+}\right), 1.0\left(\mathrm{~m},\left[\mathrm{Ni}\left(\mathrm{Me}_{2} \mathrm{PCH}_{2} \mathrm{CH}_{2} \mathrm{PMe}_{2}\right)_{2}\right]^{2+}\right), 1.18(\mathrm{~m}$, $\left.\left[\mathrm{HNi}\left(\mathrm{Me}_{2} \mathrm{PCH}_{2} \mathrm{CH}_{2} \mathrm{PMe}\right)_{2}\right]^{+}\right), 1.28\left(\mathrm{~m},\left[\mathrm{Ni}\left(\mathrm{Me}_{2} \mathrm{PCH}_{2} \mathrm{CH}_{2} \mathrm{PMe}_{2}\right)_{2}\right]^{2+}\right), 1.55(\mathrm{~m}$, $\left.\left[\mathrm{HNi}\left(\mathrm{Me}_{2} \mathrm{PCH}_{2} \mathrm{CH}_{2} \mathrm{PMe}_{2}\right)_{2}\right]^{+}\right) .{ }^{31} \mathbf{P}\left\{{ }^{1} \mathbf{H}\right\} \mathbf{N M R}\left(\mathrm{C}_{6} \mathrm{D}_{5} \mathrm{Cl}, 121 \mathrm{MHz}\right): \delta 24.3$ $\left(\left[\mathrm{HNi}(\mathrm{dmpe})_{2}\right]^{+}\right), 43.0\left(\left[\mathrm{Ni}(\mathrm{dmpe})_{2}\right]^{2+}\right) .{ }^{19} \mathbf{F ~ N M R}\left(\mathrm{C}_{6} \mathrm{D}_{5} \mathrm{Cl}, 282 \mathrm{MHz}\right): \delta-165.35(\mathrm{~m}, 6 \mathrm{~F})$, $-160.38\left(\mathrm{t}, J_{\mathrm{FF}}=20.6 \mathrm{~Hz}, 3 \mathrm{~F}\right),-134.64(\mathrm{~m}, 6 \mathrm{~F}) .{ }^{11} \mathbf{B} \mathbf{N M R}\left(\mathrm{C}_{6} \mathrm{D}_{5} \mathrm{Cl}, 160 \mathrm{MHz}\right): \delta-0.48$ (br).

\section{$\mathrm{CO}_{2}$ reductions by nickel and boranes in acetonitrile}

General procedure for reactions of $\left[\mathrm{HNi}(\mathrm{dmpe})_{2}\right]\left[\mathrm{PF}_{6}\right]$ in acetonitrile-A JYoung NMR tube was charged with $\left[\mathrm{HNi}(\mathrm{dmpe})_{2}\right]\left[\mathrm{PF}_{6}\right](\sim 0.03 \mathrm{mmol})$, the appropriate amount of ${ }^{t} \mathrm{Bu}\left(\mathrm{CH}_{2}\right)_{2} \mathrm{~B}\left(\mathrm{C}_{8} \mathrm{H}_{14}\right)\left(0,1,10\right.$ equiv), and $\sim 0.6 \mathrm{~mL} \mathrm{CD}_{3} \mathrm{CN}$. The tube was sealed, initial NMR measurements were taken, and the atmosphere replaced with $1 \mathrm{~atm} \mathrm{CO}_{2}$ (after freeze-pump-thaw degassing twice). The reactions were monitored periodically by multinuclear NMR spectroscopy until equilibrium was reached (under 24 hours), with conversion at equilibrium estimated by integration.

$\mathrm{CO}_{2}$-In the absence of trialkylborane, only about 5\% hydride transfer was observed. The only two species observed in solution were unreacted $\left[\mathrm{HNi}(\mathrm{dmpe})_{2}\right]^{+}$and small amounts of $\left[\mathrm{Ni}(\mathrm{dmpe})_{2}\right]^{2+}$.

1 equiv ${ }^{t} \mathrm{Bu}\left(\mathrm{CH}_{2}\right)_{2} \mathrm{~B}\left(\mathrm{C}_{8} \mathrm{H}_{14}\right)$ and $\mathrm{CO}_{2}$-When one equivalent of trialkylborane was added, about $65 \%$ hydride transfer was observed.

10 equiv ${ }^{t} \mathrm{Bu}\left(\mathrm{CH}_{2}\right)_{2} \mathrm{~B}\left(\mathrm{C}_{8} \mathrm{H}_{14}\right)$ and $\mathrm{CO}_{2}$-When excess trialkylborane was added, nearly quantitative hydride transfer was observed. Only a trace of unreacted $\left[\mathrm{HNi}(\mathrm{dmpe})_{2}\right]^{+}$was observed.

Reaction of $\left[\mathrm{Ni}\left(\mathrm{dmpe}_{2}\right]\left[\mathrm{PF}_{6}\right]_{2}\right.$ with $\left[\mathrm{Bu}_{4} \mathrm{~N}\right]\left[\mathrm{HCO}_{2}\right]-\mathrm{A}$ small vial was charged with $19.7 \mathrm{mg}(0.0359 \mathrm{mmol})\left[\mathrm{Ni}(\mathrm{dmpe})_{2}\right]\left[\mathrm{PF}_{6}\right]_{2}$ and $10.3 \mathrm{mg}(0.0359 \mathrm{mmol})$, and $\sim 0.6 \mathrm{~mL}$ $\mathrm{CD}_{3} \mathrm{CN}$. As the mixture was stirred a color change from yellow to dark orange was observed. The mixture was transferred to a J-Young NMR tube, and monitored. The color faded to a lighter orange over a few minutes. After 15 minutes, almost complete conversion $(\sim 95 \%)$ to $\left[\mathrm{HNi}(\mathrm{dmpe})_{2}\right]\left[\mathrm{PF}_{6}\right]$ was observed, although a slight excess of $\left[\mathrm{HCO}_{2}\right]^{-}(\delta 8.58)$ was still present.

Addition of $\left[\mathrm{Bu}_{4} \mathrm{~N}\right]\left[\mathrm{HCO}_{2}\right]$ after reduction-A 1:10 mixture of [ $\left.\mathrm{HNi}(\mathrm{dmpe})_{2}\right]\left[\mathrm{PF}_{6}\right]$ and ${ }^{t} \mathrm{Bu}\left(\mathrm{CH}_{2}\right)_{2} \mathrm{~B}\left(\mathrm{C}_{8} \mathrm{H}_{14}\right)$ was treated with $\mathrm{CO}_{2}$ according to the general procedure. After the reaction was complete the tube was brought into a glovebox and 1 equiv $\left[\mathrm{Bu}_{4} \mathrm{~N}\right]\left[\mathrm{HCO}_{2}\right]$ was added to the tube. The resonance at $\delta 8.210$ roughly doubled in intensity (and shifted by only $0.003 \mathrm{ppm}$ ), thereby confirming that formate is the product of $\mathrm{CO}_{2}$ reduction.

Reaction of [HNi(dmpe $\left.)_{2}\right]^{+}$and ${ }^{t} \mathrm{Bu}\left(\mathrm{CH}_{2}\right)_{2} \mathrm{~B}\left(\mathrm{C}_{8} \mathrm{H}_{14}\right)$ with ${ }^{13} \mathrm{CO}_{2}-\mathrm{A} \mathrm{J}$-Young NMR tube was charged with $18.9 \mathrm{mg}(0.0374 \mathrm{mmol})\left[\mathrm{HNi}(\mathrm{dmpe})_{2}\right]\left[\mathrm{PF}_{6}\right], 38.6 \mathrm{mg}(0.187 \mathrm{mmol}, 5$ equiv) ${ }^{t} \mathrm{Bu}\left(\mathrm{CH}_{2}\right)_{2} \mathrm{~B}\left(\mathrm{C}_{8} \mathrm{H}_{14}\right)$, and $\sim 0.6 \mathrm{~mL} \mathrm{CD} \mathrm{CD}_{3} \mathrm{CN}$. After initial NMR spectroscopic measurements, the tube was subjected to two freeze-pump-thaw cycles, and $0.0187 \mathrm{mmol}$ (0.5 equiv) ${ }^{13} \mathrm{CO}_{2}$ was condensed from a $2.87 \mathrm{~mL}$ calibrated gas bulb $(11.8 \mathrm{mmHg})$. About $5 \%$ conversion to $\left[\mathrm{Ni}(\mathrm{dmpe})_{2}\right]\left[\mathrm{PF}_{6}\right]_{2}$ had occurred after 30 minutes, and a small doublet could be seen by ${ }^{1} \mathrm{H}$ NMR. After 12 hours, a large doublet at $\delta 8.21(202 \mathrm{~Hz})$ was visible, consistent with formation of $\left[\mathrm{H}^{13} \mathrm{CO}_{2}\left(\mathrm{BR}_{3}\right)_{\mathrm{n}}\right]^{-}$. 


\section{Attempted catalytic reactions}

Attempted catalysis in acetonitrile-A J-Young NMR tube was charged with $5.0 \mathrm{mg}$ (0.0102 mmol, 1 equiv) $\left[\mathrm{Ni}(\mathrm{dmpe})_{2}\right]\left[\mathrm{BF}_{4}\right]_{2}, 7.1 \mu \mathrm{L}\left(0.0511 \mathrm{mmol}, 5\right.$ equiv) $\mathrm{NEt}_{3}, 10.5 \mathrm{mg}$ (0.0511 mmol, 5 equiv) ${ }^{t} \mathrm{Bu}\left(\mathrm{CH}_{2}\right)_{2} \mathrm{~B}\left(\mathrm{C}_{8} \mathrm{H}_{14}\right)$, and $\sim 0.6 \mathrm{~mL} \mathrm{CD}{ }_{3} \mathrm{CN}$. The tube was subjected to two freeze-pump-thaw cycles, and $1 \mathrm{~atm}$ of a $1: 1 \mathrm{H}_{2}: \mathrm{CO}_{2}$ mixture (mixed in a large round bulb on a vacuum line) was admitted. The reaction was monitored by NMR spectroscopy, and a small formate peak gradually grew in over 3 days, along with another product, $\delta \sim 6.8$. Heating the tube to $60{ }^{\circ} \mathrm{C}$ for $\sim 24$ hours generated visible amounts of $\left[\mathrm{HNi}(\mathrm{dmpe})_{2}\right]^{+}$, but also several unidentified products.

Attempted catalysis in chlorobenzene-A J-Young NMR tube was charged with 35.5 $\left.\mathrm{mg}(0.0174 \mathrm{mmol}, 1 \text { equiv) [Ni(dmpe })_{2}\right]\left[\mathrm{BAr}_{4}{ }_{4}\right]_{2}, 10.0 \mu \mathrm{L}$ (0.0695 mmol, 4 equiv) $\mathrm{NEt}_{3}$, $3.6 \mathrm{mg}\left(0.0174,1\right.$ equiv) ${ }^{t} \mathrm{Bu}\left(\mathrm{CH}_{2}\right)_{2} \mathrm{~B}\left(\mathrm{C}_{8} \mathrm{H}_{14}\right)$, and $\sim 0.6 \mathrm{~mL} \mathrm{C}_{6} \mathrm{D}_{5} \mathrm{Cl}$. The $\mathrm{Ni}^{2+}$ formed a yellow oil at the bottom of the tube if it was allowed to settle. The tube was subjected to two freeze-pump-thaw cycles, and $1 \mathrm{~atm}$ of a 1:1 mixture of $\mathrm{H}_{2}: \mathrm{CO}_{2}$ (mixed in a large round bulb on a vacuum line) was admitted to the tube. NMR spectroscopic monitoring showed steady generation of $\left[\mathrm{HNi}(\mathrm{dmpe})_{2}\right]\left[\mathrm{BAr}_{4} \mathrm{~F}_{4}\right]$, but no evidence of formate was observed.

\section{Hydrogen cleavage reactions}

Hydrogen cleavage in acetonitrile-A J-Young NMR tube was charged with $32.6 \mathrm{mg}$ $(0.0159 \mathrm{mmol})\left[\mathrm{Ni}(\mathrm{dmpe})_{2}\right]\left[\mathrm{BAr}_{4}\right]_{2}, 8.9 \mu \mathrm{L}\left(0.0639 \mathrm{mmol}, 4\right.$ equiv) $\mathrm{NEt}_{3}$, and $\sim 0.6 \mathrm{~mL}$ $\mathrm{CD}_{3} \mathrm{CN}$. The tube was subjected to two freeze-pump-thaw cycles and $1 \mathrm{~atm}$ of $\mathrm{H}_{2}$ was admitted. The reaction was monitored by NMR spectroscopy, revealing about $30 \%$ conversion to $\left[\mathrm{HNi}(\mathrm{dmpe})_{2}\right]^{+}$over 3 days.

Hydrogen cleavage in chlorobenzene-A J-Young NMR tube was charged with 29.0 $\mathrm{mg}(0.0140 \mathrm{mmol})\left[\mathrm{Ni}(\mathrm{dmpe})_{2}\right]\left[\mathrm{BAr}_{4}\right]_{2}, 7.9 \mu \mathrm{L}$ (0.0568 mmol, 4 equiv) $\mathrm{NEt}_{3}$, and $\sim 0.6 \mathrm{~mL}$ $\mathrm{C}_{6} \mathrm{D}_{5} \mathrm{Cl}$. The Ni dication was insoluble, and formed an oil at the bottom of the tube. Initial NMR measurements detected no Ni species. The tube was subjected to two freeze-pumpthaw cycles and $1 \mathrm{~atm} \mathrm{H}_{2}$ was admitted. The tube was sealed and monitored by NMR, which revealed relatively rapid growth of $\left[\mathrm{HNi}(\mathrm{dmpe})_{2}\right]\left[\mathrm{BAr}_{4}\right]$. After 18 hours, no insolubles were visible, and a large amount of Ni hydride was present. The two phase reaction prevented precise yields or equilibrium measurements.

\section{$\mathrm{CO}_{2}$ reduction by rhodium and boranes in acetonitrile}

Reaction of [Rh(dmpe) $)_{2}$ [OTf] with $\mathrm{H}_{2} / \mathrm{CO}_{2}-\mathrm{A} \mathrm{J}$-Young NMR tube was charged with $19 \mathrm{mg}(0.0344 \mathrm{mmol})\left[\mathrm{Rh}(\mathrm{dmpe})_{2}\right][\mathrm{OTf}]$ and $\sim 0.6 \mathrm{~mL} \mathrm{CD}_{3} \mathrm{CN}$. The tube was placed under 1 atm of a 1:1 mixture of $\mathrm{H}_{2}$ and $\mathrm{CO}_{2}$, mixed by diffusion in a large round bulb on a vacuum manifold. The reaction was monitored by multinuclear NMR, which showed formation of $\left[\mathrm{H}_{2} \mathrm{Rh}(\mathrm{dmpe})_{2}\right][\mathrm{OTf}]$, but no more than a trace of formate was observed.

Reaction of [Rh(dmpe) $)_{2}$ [OTf] with ${ }^{t} \mathrm{Bu}\left(\mathrm{CH}_{2}\right)_{2} \mathrm{~B}\left(\mathrm{C}_{8} \mathrm{H}_{14}\right)$ and $\mathrm{H}_{2} / \mathrm{CO}_{2}-\mathrm{A} \mathrm{J}$-Young NMR tube was charged with $15.9 \mathrm{mg}(0.0288 \mathrm{mmol})\left[\mathrm{Rh}(\mathrm{dmpe})_{2}[\mathrm{OTf}], 5.9 \mathrm{mg}(0.0288\right.$ mmol) ${ }^{t} \mathrm{Bu}\left(\mathrm{CH}_{2}\right)_{2} \mathrm{~B}\left(\mathrm{C}_{8} \mathrm{H}_{14}\right)$, and $\sim 0.6 \mathrm{~mL} \mathrm{CD}_{3} \mathrm{CN}$. The tube was placed under $1 \mathrm{~atm}$ of a 1:1 mixture of $\mathrm{H}_{2}$ and $\mathrm{CO}_{2}$, mixed by diffusion in a large round bulb on a vacuum manifold. The reaction was monitored by NMR spectroscopy, which showed growth of signals attributable to $\left[\mathrm{H}_{2} \mathrm{Rh}(\mathrm{dmpe})_{2}\right]^{+}\left(\delta-10.25\right.$, br d, $\left.J_{\mathrm{PH}}=146.4\right)$, and eventually $\left[\mathrm{HCO}_{2}\left(\mathrm{BR}_{3}\right)_{\mathrm{n}}\right]^{-}(\delta 8.25)$ and $\left[\mathrm{HRh}(\mathrm{dmpe})_{2}(\mathrm{MeCN})\right]^{2+}(\delta-18.57, \mathrm{~m})$.

\section{Supplementary Material}

Refer to Web version on PubMed Central for supplementary material. 


\section{Acknowledgments}

This research was generously funded by BP through the Methane Conversion Cooperative $\left(\mathrm{MC}^{2}\right)$ Program and by the Moore Foundation. The Varian 400-MR spectrometer was purchased through NIH grant RR027690.

\section{References}

1. (a) Benson EE, Kubiak CP, Sathrum AJ, Smieja JM. Chem. Soc. Rev. 2009; 38:89. [PubMed: 19088968] (b) Leitner W. Angew. Chem. Int. Ed. 1995; 34:2207.(c) Jessop PG, Joó F, Tai C. Coord. Chem. Rev. 2004; 248:2425.

2. (a) Miller AJM, Labinger JA, Bercaw JE. J. Am. Chem. Soc. 2008; 130:11874. [PubMed: 18702489] (b) Elowe PR, West NM, Labinger JA, Bercaw JE. Organometallics. 200928:6218.(c) Miller AJM, Labinger JA, Bercaw JE. J. Am. Chem. Soc. 2010; 132:3301. [PubMed: 20178359] (d) Miller AJM, Labinger JA, Bercaw JE. Organometallics. 2010; 29:4499.(e) West NM, Miller A,JM, Labinger JA, Bercaw JE. Coord. Chem. Rev. 2011; 255:881.(f) West, NM.; Labinger, JA.; Bercaw, JE. Organometallics. 2011. in press

3. Rozovskii AY, Lin GI. Top. Catal. 2003; 22:137.

4. (a) Hammouche M, Lexa D, Momenteau M, Saveant JM. J. Am. Chem. Soc. 1991; 113:8455.(b) Bhugun I, Lexa D, Saveant J-M. J. Am. Chem. Soc. 1994; 116:5015.(c) Bhugun I, Lexa D, Saveant J-M. J. Phys. Chem. 1996; 100:19981.(d) Bhugun I, Lexa D, Saveant J-M. J. Am. Chem. Soc. 1996; 118:1769.(e) Gennaro A, Isse AA, Severin M-G, Vianello E, Bhugun I, Saveant J-M. J. Chem. Soc, Faraday Trans. 1996; 92:3963.(f) Saveant J-M. Chem. Rev. 2008; 108:2348. [PubMed: 18620367] (g) Wong K-Y, Chung W-H, Lau C-P. J. Electroanal. Chem. 1998; 453:161.

5. (a) Steffey BD, Curtis CJ, DuBois DL. Organometallics. 1995; 14:4937.(b) Dubois MR, Dubois DL. Ace. Chem. Res. 2009; 42:1974.(c) Jeoung J-H, Dobbek H. Science. 2007; 318:1461. [PubMed: 18048691]

6. Boffa A, Lin C, Bell AT, Somorjai GA. J. Catal. 1994; 149:149.

7. Laitar DS, Muller P, Sadighi JP. J. Am. Chem. Soc. 2005; 127:17196. [PubMed: 16332062]

8. Chakraborty S, Zhang J, Krause JA, Guan HR. J. Am. Chem. Soc. 2010; 132:8872. [PubMed: 20540579]

9. (a) Stephan DW, Erker G. Angew. Chem. Int. Ed. 2010; 49:46.(b) Ashley AE, Thompson AL, O'Hare D. Angew. Chem. Int. Ed. 2009; 48:9839.(c) Tran SD, Tronic TA, Kaminsky W, Heinekey DM, Mayer JM. Inorg. Chim. Acta. 2011; 369:126.

10. (a) Matsuo T, Kawaguchi H. J. Am. Chem. Soc. 2006; 128:12362. [PubMed: 16984155] (b) Berkefeld A, Piers WE, Parvez M. J. Am. Chem. Soc. 2010; 132:10660. [PubMed: 20681691]

11. DuBois DL, Berning DE. Appl. Organomet. Chem. 2000; 14:860.

12. (a) Berning DE, Noll BC, DuBois DL. J. Am. Chem. Soc. 1999; 121:11432.(b) Berning DE, Miedaner A, Curtis CJ, Noll BC, Rakowski DuBois MC, DuBois DL. Organometallics. 2001; 20:1832.(c) Curtis CJ, Miedaner A, Ellis WW, DuBois DL. J. Am. Chem. Soc. 2002; 124:1918. [PubMed: 11866604]

13. Wilson AD, Miller AJM, DuBois DL, Labinger JA, Bercaw JE. Inorg. Chem. 2010; 49:3918. [PubMed: 20334390]

14. Pangborn AB, Giardello MA, Grubbs RH, Rosen RK, Timmers FJ. Organometallics. 1996; $15: 1518$.

15. Miedaner A, DuBois DL, Curtis CJ, Haltiwanger RC. Organometallics. 1993; 12:299.

16. Hirano K, Yorimitsu H, Oshima K. Org. Lett. 2005; 7:4689. [PubMed: 16209511]

17. Silavwe ND, Goldman AS, Ritter R, Tyler DR. Inorg. Chem. 1989; 28:1231.

18. DuBois DL, Blake DM, Miedaner A, Curtis CJ, DuBois MR, Franz JA, Linehan JC. Organometallics. 2006; 25:4414. 
electrochemical $\mathrm{CO}_{2}$ reduction

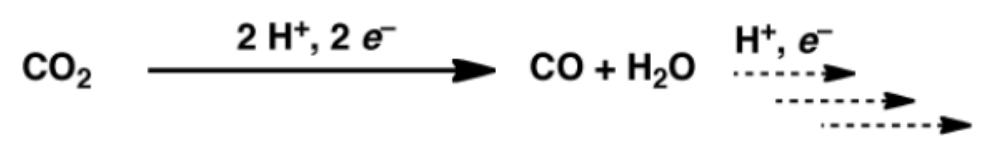

hydrogenation of $\mathrm{CO}_{2}$

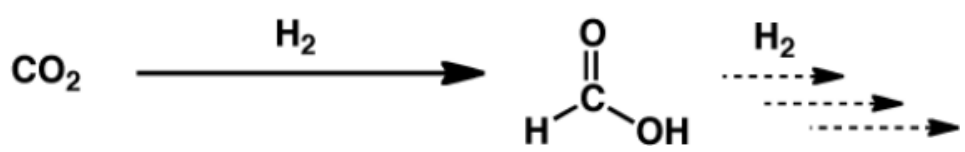

Scheme 1. 

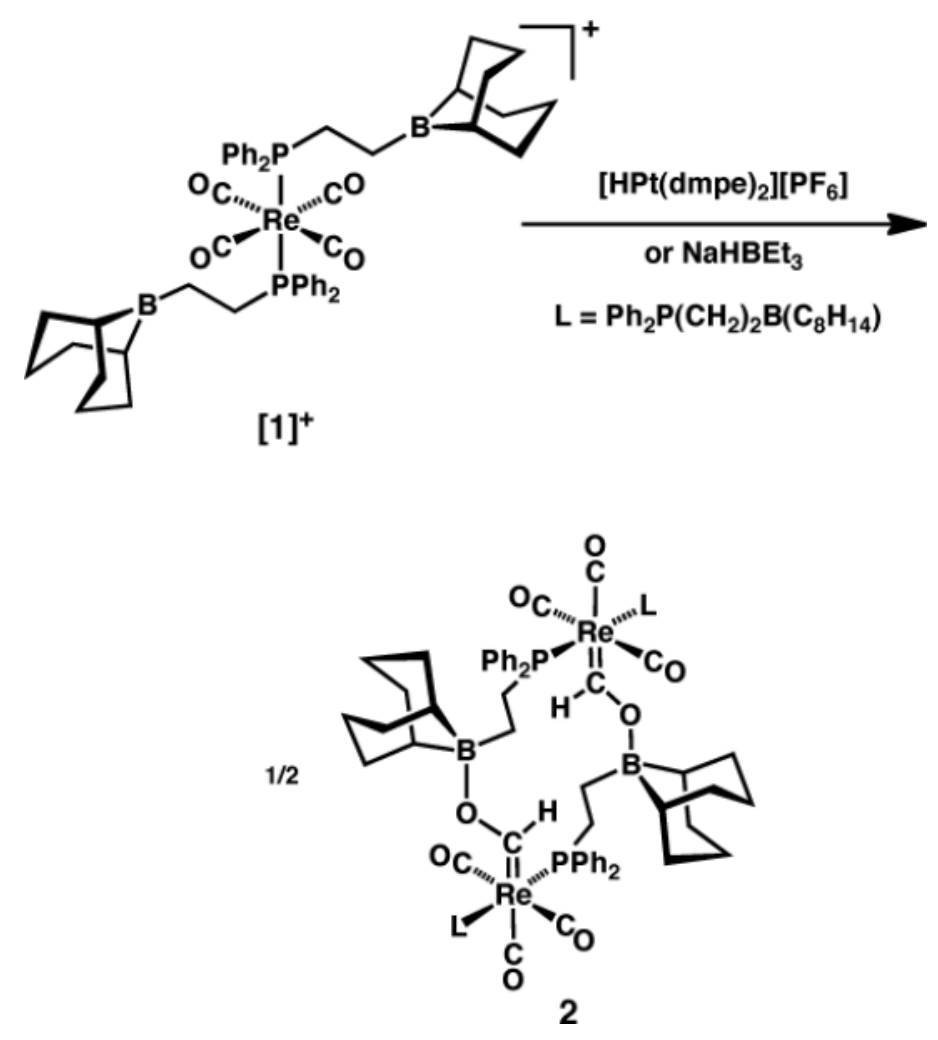

Scheme 2. 


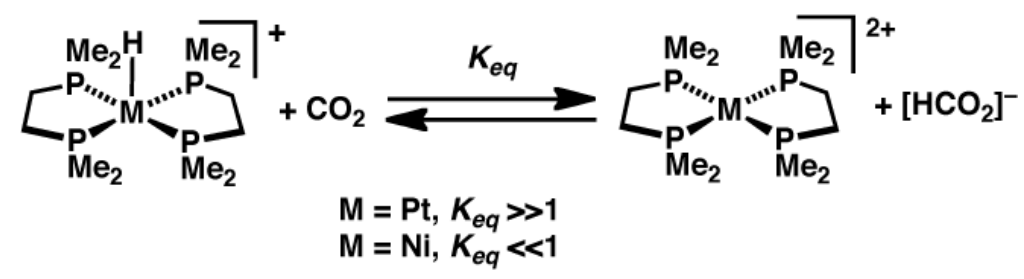

Scheme 3. 

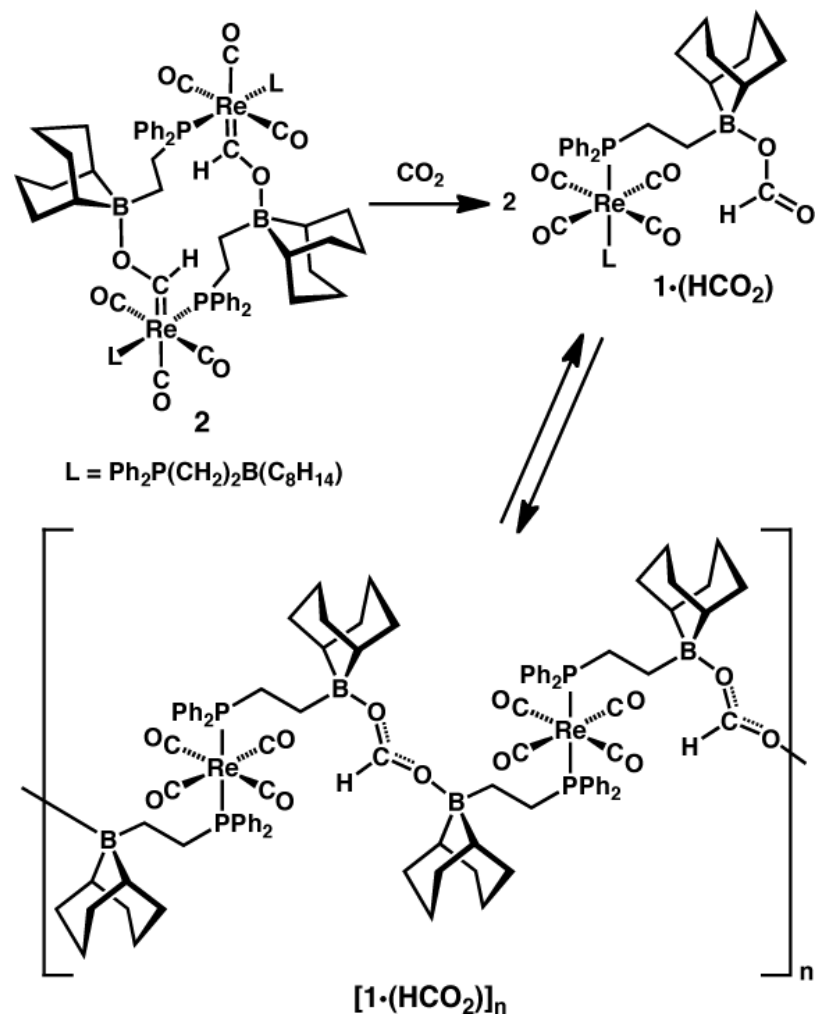

Scheme 4. 


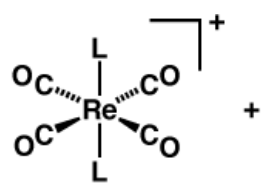

[1]

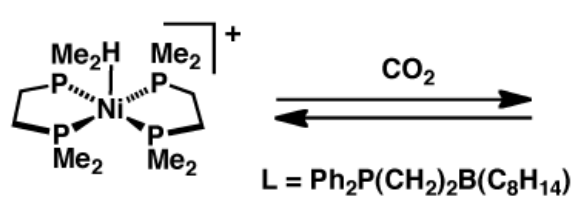

$\left[\mathrm{HNi}(\mathrm{dmpe})_{2}\right]^{+}$

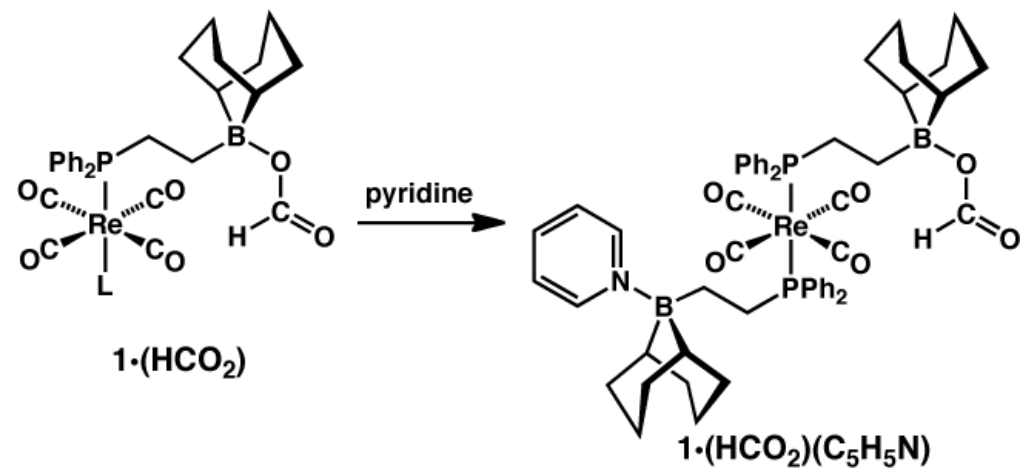

Scheme 5. 

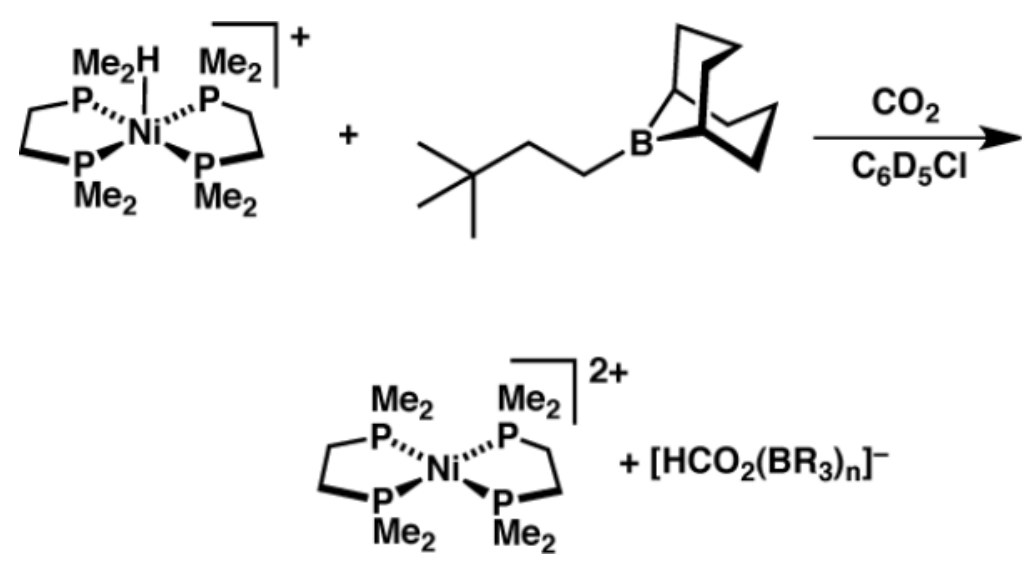

Scheme 6. 

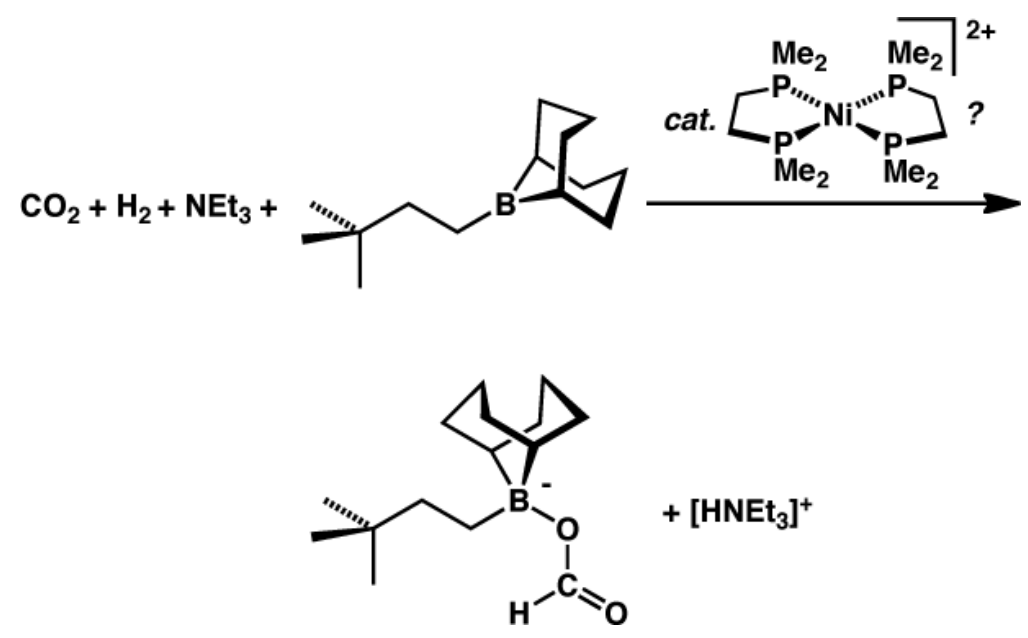

Scheme 7. 

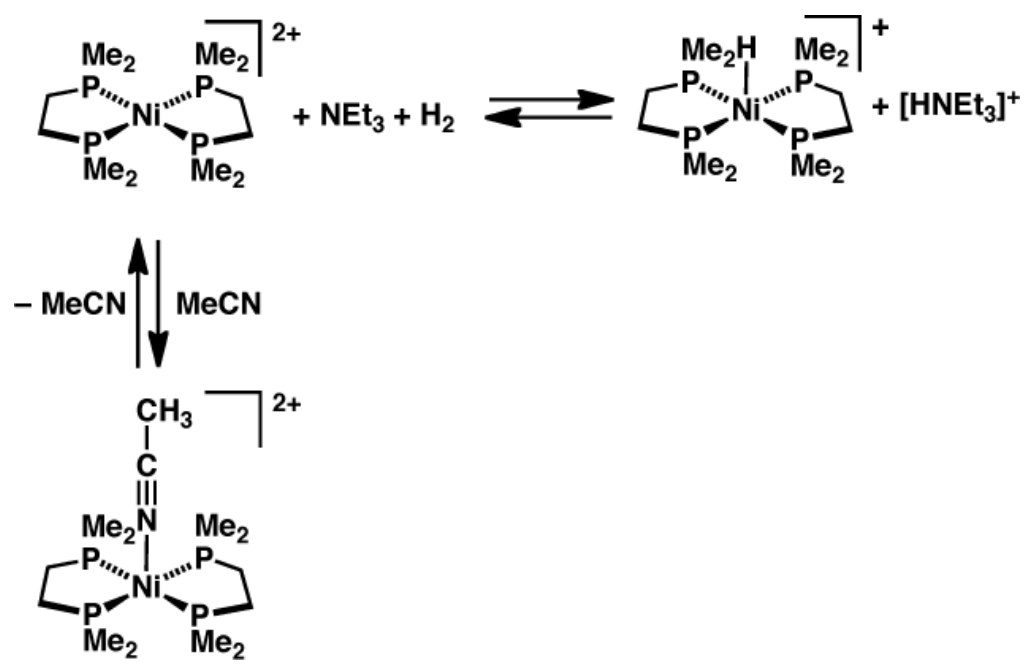

Scheme 8. 

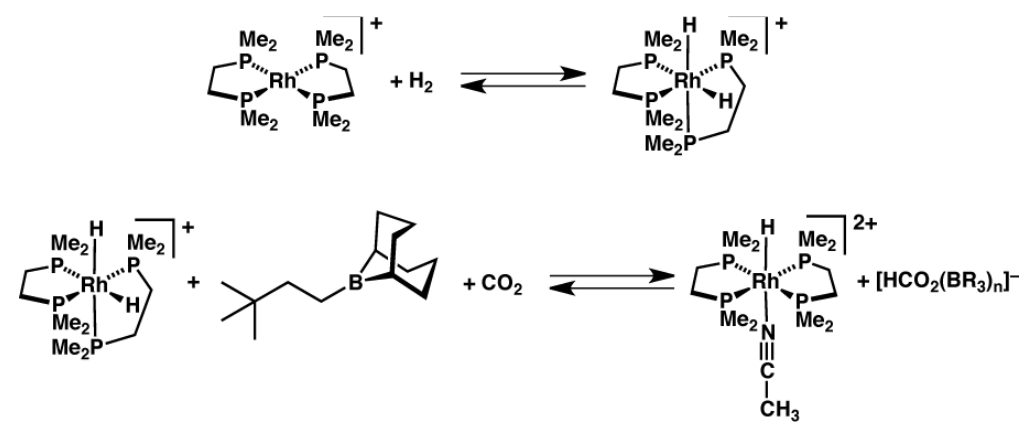

Scheme 9. 


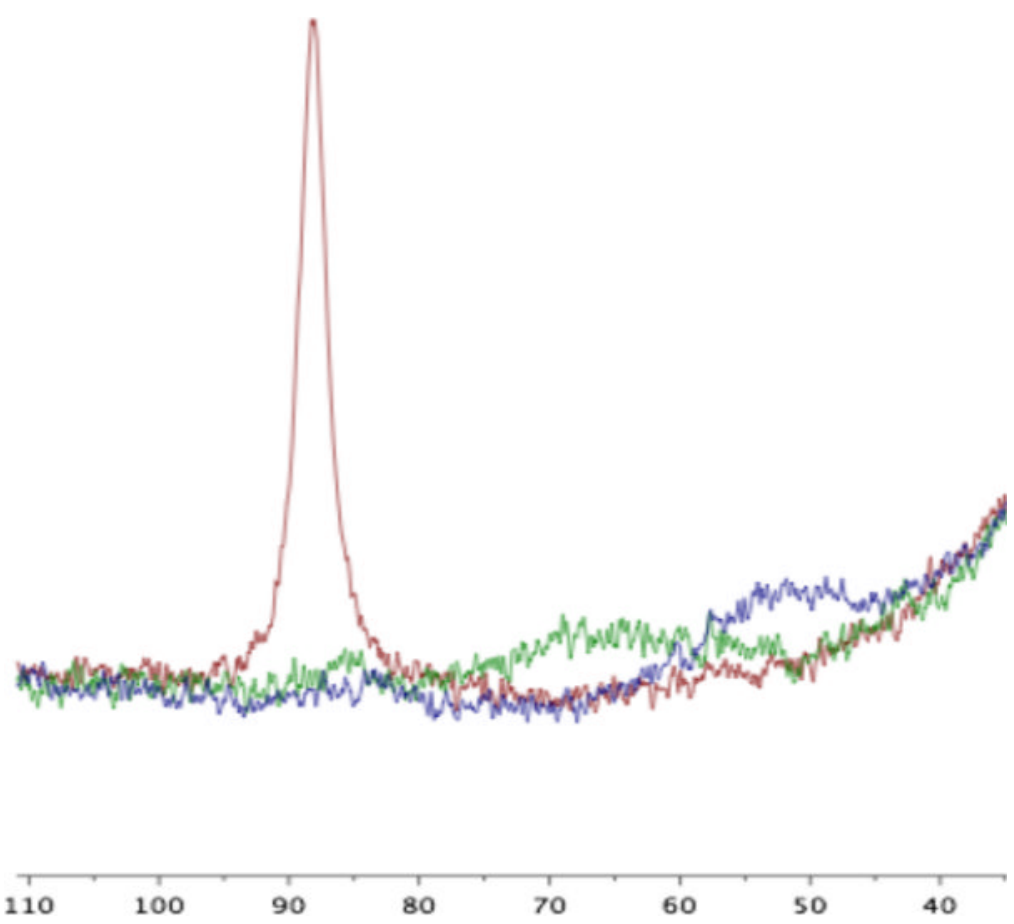

Figure 1.

${ }^{11} \mathrm{~B}$ NMR spectra of a mixture of $\left[\mathrm{HNi}(\mathrm{dmpe})_{2}\right]\left[\mathrm{PF}_{6}\right]$ and ${ }^{\mathrm{t}} \mathrm{Bu}\left(\mathrm{CH}_{2}\right)_{2} \mathrm{~B}\left(\mathrm{C}_{8} \mathrm{H}_{14}\right)$ in $\mathrm{C}_{6} \mathrm{D}_{5} \mathrm{Cl}$ before $\mathrm{CO}_{2}$ addition (red), 2 hours after addition of $\mathrm{CO}_{2}(1 \mathrm{~atm})$ (green), and after 18 hours (blue). 